\title{
Devices for cleaning tap water
}

\author{
Zhanna Govorova* , Nikita Podlesnov and Vadim Govorov
}

Moscow State University of Civil Engineering, Yaroslavskoe shosse, 26, Moscow, 129337, Russia

\begin{abstract}
The condition of the water distribution network of the centralized water supply and its high wear, at the same time with other factors, affect the quality of drinking water transported to the consumer of drinking water. The most common causes of the secondary pollution of drinking water during its transportation are considered, as a result of which the concentration of dissolved and undissolved impurities and corrosion products increases, unpleasant smells and tastes appear in the water, microbiological and parasitological indicators deteriorate. Along with measures to improve the technology of water purification at waterworks, replacement, cleaning and repair of pipelines, in practice domestic water purification devices are used. The results of studies of the effectiveness of additional purification of drinking water are presented in the article. The water is taken for analysis from different points of the Moscow distribution network on water treatment devices: "JNT-RO", filter "Aquafor", installation "OSMO 300 " with a capacity from 187.2 to 380 1/day. The results showed that the original tap water in its qualitative composition met the regulatory requirements for drinking water, and after passing through the elements of water purification devices during the stated service life the quality characteristics of turbidity - 100\%, chromaticity - 84.6-100\%, Total Dissolved Solids (TDS) - 84.4-94.2\% and hardness - 87.3-93.8\% improved. The calcium content in purified water ranged from 6.8 to 12 $\mathrm{mg} / \mathrm{l}$.
\end{abstract}

\section{Introduction}

Providing the population with quality drinking water is one of the most important tasks of our time. The quality and safety of drinking water supplied to the population through centralized water supply systems is determined not only by the state of the sources, but also by the state of the water supply and distribution networks. The main and distribution networks must provide the required amount of water and maintain quality during transportation, as well as have minimal water losses, be reliable and economical [1], but in practice this is not always possible.

Analysis of the information [2] showed that in 2017 more than 50\% of drinking water samples from water pipes did not meet the hygienic standards for sanitary and chemical indicators in the Republics of Kalmykia (71.4\%), Dagestan (67.1\%), Mordovia (66.7\%) and the Novgorod region $(51.7 \%$ ); by microbiological indicators - the Republic of Ingushetia (15.2\%), the Karachay-Cherkess Republic (14.9\%), the Nenets Autonomous District

\footnotetext{
* Corresponding author: GovorovaZhM@mgsu.ru
} 
$(14.3 \%)$ and the Smolensk Region (13.9\%). At the same time, for the period from 2012 to 2017 , there is a weak positive trend in the decline in the rate of samples that do not correspond to sanitary-chemical and bacteriological indicators (Fig. 1).
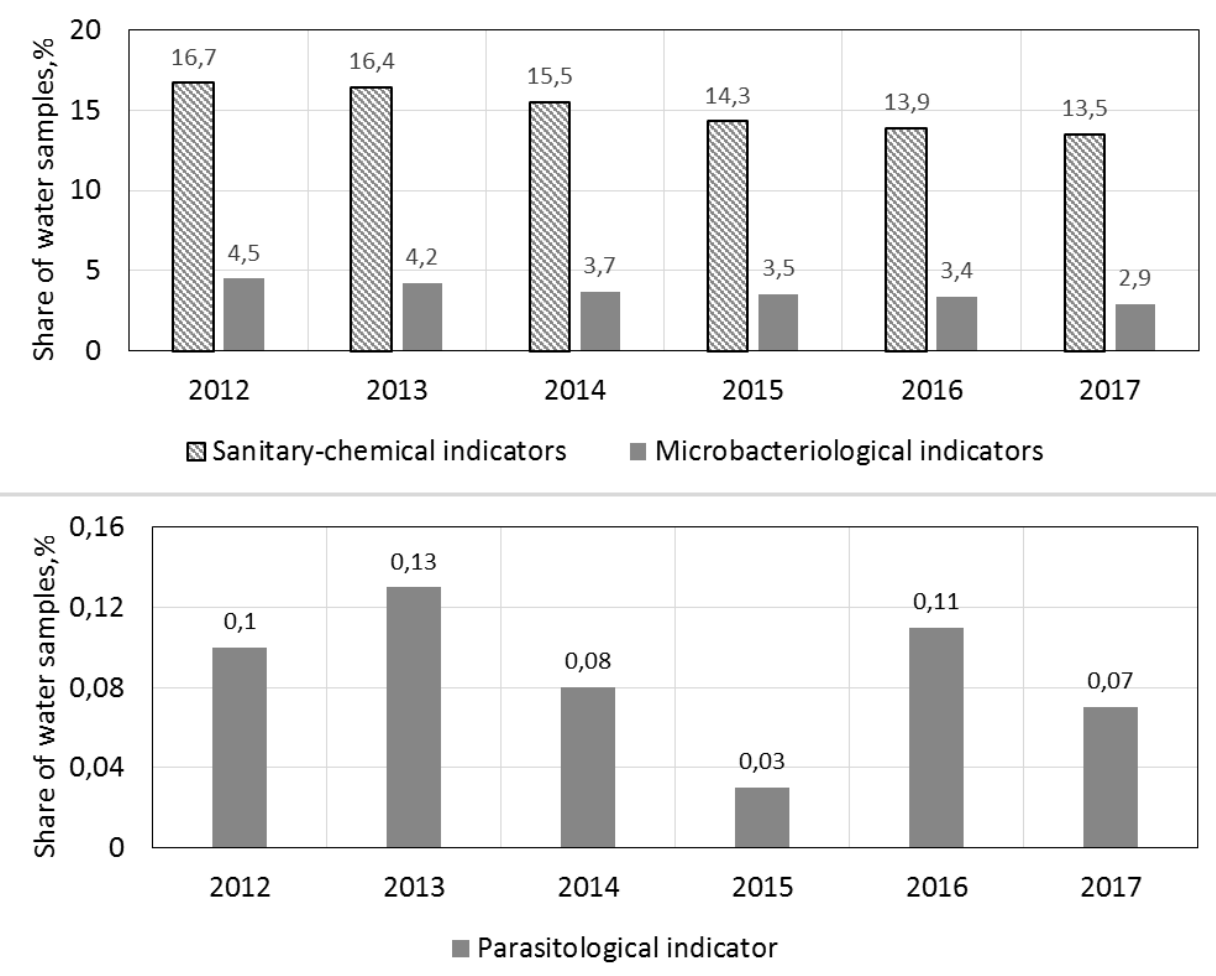

Fig. 1. The share of water samples with excess of hygienic standards for water quality indicators from the distribution network of centralized drinking water supply.

Of the chemicals that exceed the hygienic standards in drinking water samples, we can distinguish silicon, lithium, magnesium, iron, strontium, chloroform, manganese, boron, aluminum, sulfates, ammonia and nitrates. As an example, data are given for individual subjects of the Russian Federation (Table 1).

Table 1. The share of water samples from centralized drinking water supply systems with excess of hygienic standards for the content of chemicals (2017).

\begin{tabular}{|c|c|c|c|}
\hline \multirow{2}{*}{ Pollutants } & \multirow{2}{*}{$\begin{array}{c}\text { Subjects } \\
\text { of the Russian Federation }\end{array}$} & $\begin{array}{c}\text { The share of water samples with excess } \\
\text { hygienic standards, \% }\end{array}$ \\
\cline { 3 - 4 } & Kurgan Region & $2-5$ times & More than 5 times \\
\hline All substances & Amur Region & 6.4 & 4.2 \\
\hline \multirow{2}{*}{ Iron } & Yamal-Nenets A.D & 7.7 & 0.8 \\
\hline & Tomsk Region & 17.2 & 1.4 \\
\hline & \multicolumn{2}{|c}{} \\
\hline
\end{tabular}




\begin{tabular}{|c|c|c|c|}
\hline & Tyumen Region & 20.8 & 5.9 \\
\hline \multirow{2}{*}{ Strontium } & Novgorod Region & 18.2 & 9.6 \\
\hline \multirow{2}{*}{ Nitrates (по $\left.\mathrm{NO}_{3}\right)$} & Bryansk Region & 9.1 & 4.1 \\
\hline \multirow{2}{*}{ Kaluga Region } & Loscow Region & 7.62 & - \\
\hline Chloroform & Republic of Khakassia & 3.4 & 0.1 \\
\hline & Volgograd Region & 36.3 & 0.01 \\
\hline & Kirov Region & 8.3 & - \\
\hline & Arkhangelsk Region & 8.2 & 0.4 \\
\hline
\end{tabular}

Summarizing the above information, we can conclude that the quality of tap water is influenced by two main factors - the lack of the necessary complex of treatment facilities and significant deterioration of water supply networks, which in some regions reaches 60$70 \%$ [3]. The latter circumstance leads to the fact that in some areas the proportion of water samples from the water supply network that do not meet hygienic standards is higher than from sources of centralized water supply. In other words, in the process of water preparation and transportation of water to consumers there is a deterioration in its quality. The most common causes of drinking water contamination during transportation [4-6] include:

- The unsatisfactory condition of the water pipes, which is the cause of the increased iron content, the appearance of undesirable water color or the smell of hydrogen sulfide;

- Sealing failure of water pipes, as a result of which various impurities enter the system, mainly large mechanical particles that impair the organoleptic properties of water;

- The use of steel water pipes without corrosion protection, subject to destruction, due to intense corrosion [7, 8];

- Residual compounds of suspended substances, aluminum, iron and phytoplankton can form loose deposits on the walls of pipelines (especially in areas with low water speeds), which are washed away with the flow of water over time and get to the consumer;

- During prolonged stay of water in the distribution network, a stagnant smell, turbidity, as well as a slight increase in chloroform concentration due to the increased time of contact of water with chlorine $[9,10]$;

- Violation of regulations for carrying out repair work, accidents, malfunctioning of water fittings, improper operation of the water supply network. 
Table 2 shows the concentrations of trihalomethanes in drinking water transported to the consumer [11-14].

Table 2. The concentration of trihalomethanes in the drinking water

\begin{tabular}{|c|c|c|}
\hline Location of the waterworks & Water source & THM ( $\boldsymbol{\mu g} / \mathbf{l})$ \\
\hline $\begin{array}{c}\text { Spain } \\
\text { (province of Córdoba) }\end{array}$ & reservoir Sierra Boyera & $100-150$ \\
\hline $\begin{array}{c}\text { Spain } \\
\text { (province of Huelva) }\end{array}$ & $\begin{array}{c}\text { reservoir Chanza, } \\
\text { Canal del Piedras }\end{array}$ & $26.4-32.9$ \\
\hline Columbia (Cali) & river Cauca & 12.9 \\
\hline Irak (Bagdad) & river Tigris & 41.6 \\
\hline
\end{tabular}

Due to secondary contamination, dissolved and undissolved impurities may be present in drinking water, corrosion products, unpleasant smells and tastes may appear, chemical, microbiological and parasitological indicators may deteriorate. To prevent pollution, measures are provided for the replacement, cleaning and repair of pipelines, the use of preand post-ammonization, the use of alternative disinfectants at the waterworks. In some cases, it is advisable to use household water purification devices [15-17], which are typically multistage systems that use two to five different blocks in the technology (rough filter, sorption unit, ion exchange unit, fine filter, mineralization unit), corresponding for the removal of a certain type of pollution from the water and included in the overall process chain. Primary rough filters are designed to remove mechanical impurities from the water (rust, sand, etc.) with dimensions greater than 5 microns. The sorption unit is a cassette with replaceable filter cartridges with activated carbon, designed to remove from water up to $90 \%$ of organic contaminants. The ion exchange unit is designed to purify water from hardness salts and nitrates. Fine filters are semipermeable (ultrafiltration or reverse osmosis) membrane. As a rule, roll filter systems are used, to which water is pumped under pressure that has undergone previous purification steps.

Determination of the efficiency of the work, the guaranteed resource of the water treatment device declared by the manufacturer, and the expediency of its use in a particular case is an urgent task and is of practical interest.

\section{Materials and methods}

To evaluate the effectiveness of additional purification of tap water, the following fivestage water purification devices were selected: the "JNT-RO" water after-treatment filter; filter "Aquaphor"; the "OSMO 300" installation, the general view of which is shown in Fig. 2 , and their technical characteristics in Table 3.

Tests were carried out in the laboratory of the Department of Water Supply and Wastewaters of NRU MSUCE. A research was conducted of several samples of tap water taken from the Moscow distribution network and water purified using water purification devices. Standard methods and certified equipment were used to determine quality indicators (Table 4). The efficiency of additional purification of tap water was determined in the middle of the service life of the filters after 6 months from the moment of launch. Change of filter elements and chemical washing of the membrane during the specified period of operation was not made. 


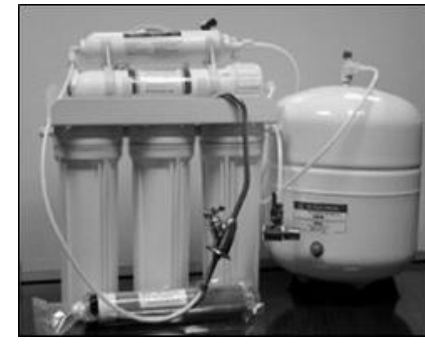

a

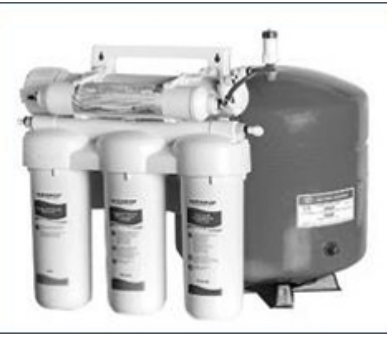

b

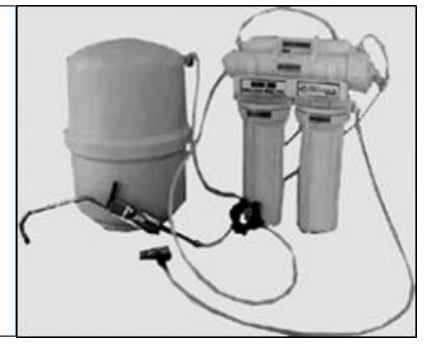

c

Fig. 2. Water treatment devices: a - "JNT-RO", b - "Aquaphor"; c - "OSMO 300".

Table 3. Technical characteristics of water treatment devices.

\begin{tabular}{|c|c|c|c|}
\hline Name & “JNT-RO" & “Aquaphor" & “OSMO 300" \\
\hline Capacity (l/day) & $190 \ldots 280$ & 187.2 & $190 \ldots 380$ \\
\hline \begin{tabular}{c} 
Clean water supply in storage tank $(1)$ \\
\hline Entry water pressure (atm)
\end{tabular} & $6 \ldots 8$ & 10 & 10 \\
\hline Water purifier (year) & $1.5 \ldots 2$ & $3.5 \ldots 6.5$ & $2.5-6$ \\
\hline Replaceable cartridges (month) & $3 \ldots 6$ & 6 & $1 . . .5$ \\
\hline Postfilter (year) & 1 & 1 & 6 \\
\hline Dimensions (mm) & $270 \times 210 \times 450$ & $390 \times 190 \times 420$ & $450 \times 150 \times 410$ \\
\hline Weight (kg) & 11 & 12 & 10.5 \\
\hline Normal temperature $\left({ }^{\circ} \mathrm{C}\right)$ & $+4 \ldots+35$ & $+5 \ldots+38$ & $+5 \ldots+30$ \\
\hline
\end{tabular}

Table 4. Equipment for determining the physical and chemical composition of water.

\begin{tabular}{|c|c|}
\hline Name & Device \\
\hline Turbidity, chromaticity & spectrophotometer Unico 210 \\
\hline $\mathrm{pH}$ & pH-мeтp HANNA HI210 \\
\hline TDS & EC-meter WTW InoLab cond730 \\
\hline Alkalinity, Hardness, $\mathrm{Ca}^{2+}$ & titrator Biohit biotrate 50ml \\
\hline
\end{tabular}

\section{Results}

Analysis of the quality of tap water from the distribution network of various administrative districts of Moscow (Table 5) showed that the water quality complied with the standards [18]. At the same time, an important factor was the content in drinking water of necessary 
macro- and microelements that can affect human health and the development of the human body both at the cellular and microlevel [19], as well as the absence of toxic substances.

Table 5. Tap water quality.

\begin{tabular}{|c|c|c|c|c|}
\hline \multirow{2}{*}{ Name } & \multicolumn{3}{|c|}{ Water sample } & SanPiN \\
\cline { 2 - 4 } & North-East AD & South-West AD & East AD & 2.1.4.1074-01 \\
\hline Turbidity (mg/l) & 0.043 & 0.04 & 0.04 & 1.5 \\
\hline $\begin{array}{c}\text { Chromaticity (degrees } \\
\text { platinum-cobalt scale) }\end{array}$ & 13 & 11 & 12 & 20 \\
\hline $\mathrm{pH}$ & 7.62 & 7.51 & 7.6 & $6-9$ \\
\hline TDS (mg/l) & 289 & 328 & 296 & 1000 \\
\hline Alkalinity (mg-eq/l) & 2.89 & 3.73 & 2.93 & - \\
\hline Hardnes (mg-eq/l) & 3.75 & 4.20 & 3.84 & 7.0 \\
\hline $\mathrm{Ca}^{2+}(\mathrm{mg}-\mathrm{eq} / \mathrm{l}(\mathrm{mg} / \mathrm{l}))$ & $2.9(116)$ & $2.73(109.2)$ & $2.8(112)$ & - \\
\hline
\end{tabular}

The analysis of the dynamics of changes in water treatment efficiency at the first system start-up and after 6 months showed that it decreases in all indicators by about 2.8-5.5\%, except for turbidity. After passing through the elements of five-stage filtration plants during the declared service life, the water improved the turbidity quality characteristics - $100 \%$, chromaticity - 84.6-100\%, TDS - 84.4-94.2\% and hardness - 87.3-93.8\%. The calcium content in purified water ranged from 6.8 to $12 \mathrm{mg} / \mathrm{l}$ (Table 6 ).

Table 6. Types of filters with floating polymer loading.

\begin{tabular}{|c|c|c|c|c|}
\hline Name & “JNT-RO" & “Aquafor" & “OSMO 300" & $\begin{array}{c}\text { SanPiN } \\
\mathbf{2 . 1 . 4 . 1 1 1 6 - 0 2}\end{array}$ \\
\hline Turbidity (mg/l) & 0 & 0 & 0 & 1,5 \\
\hline $\begin{array}{c}\text { Chromaticity (degrees } \\
\text { platinum-cobalt scale) }\end{array}$ & 2 & 2 & 0 & 20 \\
\hline $\mathrm{pH}$ & $6.5-6.65$ & 6.45 & $5.77-5,81$ & $6-9$ \\
\hline TDS (mg/l) & $37-45$ & 28 & 17 & $100-1000$ \\
\hline Alkalinity (mg-eq/l) & $0.55-0.59$ & 0.57 & 0.35 & $0.5-6.5$ \\
\hline Hardness (mg-eq/l) & $0.43-0.63$ & 0.53 & 0.24 & $1.5-7$ \\
\hline $\mathrm{Ca}^{2+}(\mathrm{mg}-\mathrm{eq} / \mathrm{l}(\mathrm{mg} / \mathrm{l}))$ & $\begin{array}{c}0.3-0,41 \\
(12-16.4)\end{array}$ & $\begin{array}{c}0.29 \\
(11.6)\end{array}$ & $\begin{array}{c}0.17-0.2 \\
(6.8-8.0)\end{array}$ & $\begin{array}{c}0.62-3.2 \\
(25-130)\end{array}$ \\
\hline
\end{tabular}

A comparative analysis of the values of salt content, hardness and calcium content with the current standards SanPiN 2.1.4.116-02 [20] showed that they are lower respectively in 2.25.9; 2.4-6.25 and 1.5-3.7 times. Thus, in this case, water cannot be categorized as physiologically complete, which in turn is determined by the salt composition of the water 
corresponding to the biological needs of the human body. The use of water by the population with a small amount of mineral substances is associated with the risk of exposure of people to toxic substances.

On this basis, in each specific case it is necessary to prove the advisability of applying additional purification of tap water in water treatment plants.

\section{Conclusions}

It has been proven that the lack of the necessary complex of treatment facilities and considerable deterioration of water supply networks have a tangible impact on the quality of drinking water. An assessment of compliance with the quality of drinking water from the distribution network of the centralized water supply of the constituent entities of the Russian Federation to hygienic standards has been carried out. The causes of occurrence and composition of the secondary contamination of drinking water are analyzed, and also various water purification devices are analyzed for its additional purification.

The analysis of tap water from the distribution network in different administrative districts of Moscow was carried out, which showed that the water from the centralized water supply system in all respects corresponded to the current regulatory requirements. The effectiveness of additional purification of tap water in five-stage filtration plants has been studied.

It was established that for six months the installations provided a standard degree of water purification, however, in terms of TDS, hardness and calcium content, purified water cannot be classified as physiologically complete.

\section{References}

1. M.G. Zhurba, L.I. Sokolov, Zh.M. Govorova, Vodosnabzheniye. Proyektirovaniye sistem $i$ sooruzheniy: vol. 3 (Publishing house of the Association of construction universities, 2019)

2. On the state of sanitary and epidemiological welfare of the population in the Russian Federation in 2017: state report (Federal Service for Supervision of Consumer Rights Protection and Human Welfare, 2018)

3. S.V. Khramenkov, O.G. Primin, V.A. Orlov, Reconstruction of pipeline systems (Publishing house of the Association of construction universities, 2008)

4. M.G. Zhurba, Zh.M. Govorova, O.B. Govorov, Vodosn. i san. tekhnika, 1-2, 12-18 (2010)

5. S.L. Kalachev, A.N. Yakubauskas, Drinking water and domestic water purification devices: consumer properties and quality expertise (Publishing House of the Russian State University of Trade and Economics, 2010)

6. A.P. Andrianov, M.G. Zhurba, Drinking water, 6, 2-18 (2009)

7. A.P. Andrianov, V.A. Chukhin, Water and Ecology: problems and solutions, 3, 18-34 (2016)

8. V.A. Chukhin, A.P. Andrianov, Vodosn. i san. tekhnika, 5, 32-49 (2015)

9. T.I. Iksanova, A.G. Malysheva, Ye.G. Rastyannikov, N.A. Yegorova, G.N. Krasovskiy, M.G. Nikolayev, Hygiene and sanitation 2, 8-12 (2006)

10. G.N. Krasovskiy, N.A. Yegorova, Hygiene and sanitation, 1,17-21 (2006) 
11. D. Tello, A.A. Borrego, T. García-Barrera, J.L. Gómez Arisa, Cong. Nac. del medio ambiente (2012) Available at: https://www.researchgate.net/publication/318987317/download

12. M. De la Cruz Vera, L. Soler Nieto, J.L. Criado González, M.P. Llavero del Pozo, J.I. Vílchez Zamorro, J.M. Palero Sanz, Tecnoaqua, 2, 42-50 (2013)

13. S. Arjona, P. Torres, C. Cruz, D. Loaiza, J. Escobar, Rev. Ing. Un. de Medellín, 11/20, 57-65 (2012)

14. Zh. Govorova, G. Gorenko, U. Rudich, V. Govorov, MATEC Web Conf. v. 251 03032 (2018) Available at: https://doi.org/10.1051/matecconf/201825103032

15. V.Ya. Varshavskiy, G.I. Nikoladze, Yu.A. Rakhmanin, L.I. Skvortsov, A.B. Cheskis, Installations (filters) for the purification of drinking water (Academy of Public Utilities, 1998)

16. Yu.A. Rakhmanin, L.F. Kiryanova, A.P. Maslyukov, A.B. Cheskis, Standards and quality 1, 19-20 (1994)

17. GOST 1952-2012 (State Standard) Water treatment for units. General requirements and methods of efficiency determination Available at: http://docs.cntd.ru/document/1200096959

18. SanPiN (Sanitary Rules and Regulations) 2.1.5.980-00. Hygienic requirements for surface water protection (Morkniga, 2017)

19. S.M. Chesnokova, A.A. Podolets, O.V. Savelyev, Vodosn. i san. tekhnika 4, 6-12 (2018)

20. SanPiN 2.1.4.1116-02 (Sanitary Rules and Regulations) Drinking water. Hygienic requirements for prepacked water quality. Quality control Available at: http://docs.cntd.ru/document/901816045 